\section{CHOICE OF CRITERIA FOR SETTING CORRESPONDENCE BETWEEN TERMS IN KNOWLEDGE BASES (p. 65-67)}

Vasyl Lyashkevych, OksanaOlar

In constructing bases or warehouses of knowledge, ontology of the arbitrary thematic branch, the issue of choosing the method of setting correspondence between terms (concepts) is always topical.

Among the many approaches to setting the correspondence between the terms in bases or warehouses of the knowledge domain "Intelligence diagnostics of computer means" the most common is the use of tables with diagnostic information such as "object - property", which can be described by Cartesian product. But using a binary relation, we can answer the question: "Is there the relation?"

Today it would be expedient to get the answer to the question: "Which of diagnostic means are more effective?" The answer to this question can be obtained from the diagnostics results.

The normalized value of diagnostics software efficiency can be used for setting correspondence between terms (concepts) such as "Object - Property" for example, in the table of knowledge "Models of computer means - Diagnostics means" and others

Keywords: computer means, intelligence diagnostics, ontology, knowledge base, knowledge table

\section{References}

1. Lokazyuk, V. M., Pomorova, V. O., Olar, O. Ya. (2009). The method of obtaining knowledge for intelligence diagnostic systems of microprocessor systems. Scientific Bulletin of Khmelnytskyi National University, 4 (137), 153-159.

2. Pomorova, O. V. (2007). Theoretical foundations, methods and means of intelligence diagnostics computer systems. Khmelnytskyi, Ukraine: Triada-M, 253.

3. Lokazyuk, V. M., Pomorova, O. V., Dominov, A. O. (2001). Intelligence diagnostic of microprocessor devices and systems. Khmelnytskyi, Ukraine: Taki Spravy, 286.

4. Pomorova, O. V. (2007). Software tools of intelligence diagnostics of computer means. Scientific Bulletin of Khmelnytskyi National University, 2, 104-106.

5. Lyashkevych, V. Ya., Olar, O. Ya., Kinashchuk, O. I. (2007). Evaluating the efficiency of diagnosing hard drives by modern software tools. Scientific Bulletin of Khmelnytskyi National University, 6, 96-99.

6. Olar, O. Ya., Lyashkevych, V. Ya., Lyashkevych, M. Yu. (2008). Expert evaluation of the efficiency of software diagnostic tools of hard drives. Scientific Bulletin of Chernivtsi National University. Physics. Electronics. Chernivtsi, Ukraine: Ruta, P.1., 423, 110-116.

7. Beshelev, S. D., Gurvich, F. G. (1973). Expert estimates. Moscow, USSR: Nauka, 291.

8. Yerina, A. M. (2001). Statistical modeling and forecasting. Kiev, Ukraine: KNEU, 170.

9. Lytvak, B. G. (1982). Expert information: Methods for obtaining and analyzing. Moscow, USSR: Radio and communication, 273.

10. Lyashkevych, V. Ya., Makarchuk, R. I., Nadeev, A. V. (2013). Using situational approach for buildan ontology of subject domain «Intelligence diagnostic of computer means». Scientific Bulletin of Khmelnytskyi National University, 5, 152-158.

\section{MEASUREMENT OF CHARACTERISTICS OF ORGANIC TRANSISTOR STRUCTURES (p. 68-72)}

\section{Zenon Gotra, Natalia Kus, Vladislav Cherpak, Pavlo Stakhira, Gregory Barylo}

The system for measuring parameters of organic transistor structures was proposed and developed in the paper. Circuit diagram was simulated in the software environment Proteus.

Output and transfer current-voltage characteristics of organic transistor structures were studied.

To develop a measuring system, modern elements of electronic equipment were used. Current-voltage characteristics, which show the work of organic transistor structures were shown, such as output and transfer characteristics, that is the dependence of the drain-source current $\left(\mathrm{I}_{\mathrm{ds}}\right)$ on the drain-source voltage $\left(\mathrm{V}_{\mathrm{ds}}\right)$ and gate voltage $\left(\mathrm{V}_{\mathrm{g}}\right)$. The studies at different gate voltages $\mathrm{V}_{\mathrm{g}}=0 \div 100 \mathrm{~V}$ with the interval $10 \mathrm{~V}$ were conducted. It is shown that at the increase in the gate voltage, the drain-source current $\left(\mathrm{I}_{\mathrm{ds}}\right)$ increased within about $0.2 \mathrm{~mA} \div 0.1 \mathrm{~mA}$.

This allows to use organic FETs both in display panels and in the smart cards since in the display panels transistors are used for color control and in smart cards - for improving information transfer. (This should remain so)

Keywords: semiconductor layer, the organic transistor structures, measuring system

\section{References}

1. Cantatore, E. A. (2004). New Chance for Electronics, Proceedings of the SAFE. IEEE Organic Materials: worckshop, 27, 267-285.

2. Forrest, S. R. (2004). The path to ubiquitous and lowcost organic electronic appliances on plastic. Nature PublishingGroup, 428, 911-918.

3. Chandar, Shekar, B., Jiyeon Lee, Shi-Woo, Rhee (2004). Organic Thin Film Transistors: Materials. Processes and Devices, 21(1), 267-285.

4. Gilles, Horowitz (1998). Organic Field-Effect Transistors. Advenced materials, 10, 365-371.

5. Shi-Woo, Rhee, Dong-Jin, Yun (2008). Metal-semiconductor contact in organic thin film transistors. J. Mater. Chem., 18, 5437-5444.

6. Clarisse, C., Riou, M. T., Geuneau, M., Le Conntellec, M. (1988). Field-effect transistor with diphthalocyanine thin film. Electron.Lett., 24, 674.

7. Cherpak, V., Stakhira, P., Khomyak, S., Volunuyk, D., Voznyak, L., Hotra, Z., Sorokin, V., Rybalochka, V., Oliynyk, O. (2011). Properties of 2,6-di-tert.-butyl-4(2,5-diphenyl-3,4-dihydro-2H-pyrazol-3-yl)-phenol as hole-transport material for life extension of organic light emitting diodes. Opt. Mat., 33, 1727-1731.

8. Tereschyuk, R. M. ( 1989). Semiconducting receivingamplifying devices: Handbook wireless enthusiast. 4-th edition, Kiev: Science. Dumka, 800.

9. Zaumseil, Jana, Henning, Sirringhaus (2007). Electron and Ambipolar Transport in Organic Field-Effect Transistor. Chem.Rev.,107, 1296-1323.

10. Zeis, Roswitha, (2005). Single crystal field-effect transistors based on layered semiconductors/ Dissertation, 6-13. 


\section{PECULIARITY OF SEED-LAYER SYNTHESIS AND MORPHOMETRIC CHARACTERISTICS OF ZnO NANORODS (p. 72-75)}

\author{
Veronika Ulianova, Anatolii Orlov, Genadzi Pashkevich, \\ Oleksandr Bogdan
}

The obtained new results of $\mathrm{ZnO}$ hexagonal nanorods synthesis by hydrothermal method on the lithium niobate substrate with synthesized seed-layer from sol-gel were presented. Optical microscopy, scanning electron microscopy and X-ray diffractometry were used to examine the morphometric and structural characteristics of the formed structures. The "oriented channels" for deposited by sol-gel method $\mathrm{ZnO}$ seed-layers was detected after annealing for the first time. It could be evidence of crystalline structure formation of the layer and wasn't caused by the process on the interface between the layer and the substrate. It was established that the roughness of the $\mathrm{ZnO}$ seed-layer had significant influence on $\mathrm{ZnO}$ nanorods structure and caused its tilting. The diameter of single seeds had defined the diameter of nanorods obtained by hydrothermal method and was about $50 \mathrm{~nm}$, the length of nanorods was about $0,5 \mu \mathrm{m}$. Average aspect ratio was equal to 9.3. The $\mathrm{ZnO}$ rod structures were regularly situated all over the substrate surface and had single-crystal structure. It is expected that vertically oriented $\mathrm{ZnO}$ structures can be obtained on smooth seedlayer, formed at adjusted process parameters such as sol-gel concentration and annealing temperature. The synthesized nanostructures could be applied as single functional material of nanoscale devices, such as sensing element of surface acoustic wave sensors and energy storage cells for energy harvesting due to having unique properties

Keywords: seed-layer, $\mathrm{ZnO}$ nanorods, sol-gel, hydrothermal method, tilting

\section{References}

1. Jagadish, C. (2006). Zinc Oxide Bulk, Thin Films and Nanostructures: Processing, Properties, and Applications. Amsterdam, Netherlands: Elsevier, 859.

2. Umit Ozgur, Hadis Morkoc (2010). ZnO devices and applications: a review of current status and future prospects. Proceedings of the IEEE, 89 (7), 1255-1268.

3. Banerjee, D., Rybczynski, J., Huang, J. Y., Wang, D. Z., Kempa, K., Ren, Z. F. (2005). Large hexagonal arrays of aligned ZnO nanorods. Appl. Phys. A., 80, 749-752.

4. Park, W. I., Kim, D. H., Jung, S. W., Yi, G. C. (2002). Metalorganic vapor-phase epitaxial growth of vertically well-aligned ZnO nanorods. Appl. Phys. Lett., 80, 42324234.

5. Orlov, A., Ulianova, V., Yakimenko Yu., Bogdan O., Pashkevich G. (2013). Synthesis of ZnO Nanorods for Acoustic Wave Sensor. IEEE XXXIII International Scientific Conference Electronics and Nanotechnology (ELNANO), 25-27.

6. Solis-Pomar, F., Martinez, E., Melendrez, M. F., PerezTijerina E. (2011). Growth of vertically aligned $\mathrm{ZnO}$ nanorods using textured $\mathrm{ZnO}$ films. Nanoscale Research Letters, 6:524, 11.

7. Shr-Nan Bai, Shich-Chuan Wu (2011). Synthesis of ZnO nanowires by the hydrothermal method, using sol-gel prepared $\mathrm{ZnO}$ seed films. Journal of Materials Science: Materials in Electronics, 22 (4), 339-344.

8. Haikuo Sun, Ming Luo, Wenjian Weng, Kui Cheng, Piyi Du, Ge Shen, Gaorong Han (2008). Room-temperature preparation of $\mathrm{ZnO}$ nanosheets grown on $\mathrm{Si}$ substrates by a seed-layer assisted solution route. Nanotechnology, 19 (12), 5.

9. Bogdan, A., Orlov, A., Ulianova, V. (2012). Growing parameters and quality of $\mathrm{ZnO}$ seed-layer film (Part 1). Electronics and Communications, 6(71), 7-13.
10. Giri, P. K., Dhar, S., Chakraborty, R. (2010). Effect of $\mathrm{ZnO}$ seed layer on the catalytic growth of vertically aligned $\mathrm{ZnO}$ nanorod arrays. Materials Chemistry and Physics, 122, 18-22.

11. Pashkevich, G. A., Gurskii, A. L., Lutsenko, E. V., Yablonskii, G. P., Trukhan, V. M.,' Yakimovich, V. N. (1991). Crystallographic orientation of imcomplete breakdown channels in $\mathrm{ZnP}_{2}$ and $\mathrm{CdP}_{2}$ monocrystals. Phys. Stat. sol., 123, 75-78.

\section{TRASFIELDERS OF FLUXES OF INDUCTION VECTORS OF ELECTROMAGNETIC FIELD OF REACTIVE COMPONENTS (p. (75-78)}

Vladimir Kudrya

The study of the ways and methods of implementation of passive reactive components of electrical circuits was conducted in the paper. In particular, it is the question about inductance coils, capacitors, transformers and other reactive components. The generalized block diagrams of functional transformations of physical quantities such as descriptors, which form their mathematical model, are given. It was proved that irrespective of the type of reactive component, all of them are characterized by the transformation of fluxes of electric induction vectors into fluxes of magnetic induction and vice versa in local volumes, which are set in a particular design. Thus, it was proved that any reactive component can be characterized as the flux transformer - transfielder.

It was shown that in isotropic media, according to the Maxwell equations, the transformation of fluxes of electric induction vectors into magnetic induction vectors and vice versa occurs in orthogonal planes. This fact allowed to set the criteria assessment of the transfielder designs optimality.

One of the main results of the study was the illustration of using not only the conduction current but also the displacement current as the derivative of the flux of electric induction vector. On this basis, the block diagram of transfielder, which uses the displacement current and serves as the transformer with capacitance input, was developed.

Thus, the proposed study is the generalized analysis of the whole class of reactive components that allowed to point out the ways of improving the existing and developing new reactive components with better performance characteristics such as reliability, frequency ranges, coordination ways and temperature modes

Keywords: reactive components, capacitor, inductance coil, flux of induction vector, capacitor transformer

\section{References}

1. Nazmul Isla, Petrenko, A. I. (2012). Microelectromechanical Systems and Devices, InTech, ISBN: 978-95351-0306-6. Chapter 8: "Macromodels of Micro-ElectroMechanical Systems (MEMS). Mode of access: WWW. URL: http://cdn.intechopen.com/pdfs/33594/InTechMacromodels_of_micro_electro_mechanical_systems_ mems _.pdf.

2. (2008). Electronics from the Bottom Up: A New Approach to Nanoelectronic Devices and Materials. Mode of access: WWW.URL: http://nanohub.org/topics/ElectronicsFromTheBottomUp.

3. (2009) A resource for nanoscience and nanotechnology, nanoHUB.org was created by the NSF-funded Network for Computational Nanotechnology. Copyright (C) 2009 NCN - Mode of access: WWW.URL: http://nanohub. org/.

4. Balakirev, M.,Vohmyakov Y., Juric A. et al (1982) Radio transmitters. M.: Radio and communication, 256.

5. Sinegub, N., Sitnikov, V. (2010). Microprocessors starlike structure with enhanced functionality. Technology and design in electronic equipment, № 4, 40-42. 
6. Joachim, K., Plever, L. Nanoscience. Revolution is not visible. - M.: Kolibri, 2009. - 235.

7. Kudrya, V. (2013). Simulation nanotechnology electronic means. Monograph. Odessa National Academy of Food Technologies - Kherson. Oldie-plus. 780. - Mode of access: http://nbuv.gov.ua/.

8. Jean, M. Raban, Anantha Chandrakasan, Borivozh Nikolic (2007). Digital integrated circuits. Design methodology. Moscow * St. Petersburg * Kiev Univ WILLIAMS-W, 911 - Mode of access: http://www.williamspublishing. com/Books/978-5-8459-1116-2.html.

9. Kudrya, V., Lyemyehov, Y., Sarkisyan, E. (2012). Physical and mathematical modeling in nanoelectronics. East European Journal of Advanced Technologies.: Volume 5 number 3 (59), 10 - 13. - Mode of access: http://journals. uran.ua/eejet/article/view/4497.

10. Kudrya, V. (2004). Systems engineering functional transformers. Proceedings of the Fifth International Scientific-Practical Conference "Modern information and electronic technologies”, Odessa, Ukraine. p. 165.

\section{ZigBee WIRELESS COMMUNICATION SYSTEM FOR TELEMEDICINE (p. 79-82)}

Grygoriy Barylo, Galyna Kuchmiy, Iryna Kremer

The authors of the paper presented the circuit design of electronic circuit of transmitting and receiving information for solving the problems of telemedicine. For simulation and configuration, Smart RF software environment was used. The simulation was carried out, and 3D visualization of system elements in the PROTEUS software was developed. The features of using telecommunication technologies of the IEE 802.15.4 standard in telemedicine infrastructure were considered. The basic requirements to the data transmission system for medical information accounting were given, and technical means for their implementation were defined. The method for constructing a wireless network of telemedicine within the locally-distributed objects was proposed. The simulation of the host device operation was carried out using modern software, which allow minimizing costs of design works and provide configuration flexibility in combination with high performance and network efficiency

Keywords: telemedicine, electronics, circuitry, wireless communication systems, ZigBee, Bluetooth, Wi-Fi

\section{References}

1. Blazis, A. K. Dyuk, V. A. (2005). Telemedicina. SPb.: "SpecLit", 154

2. Vladzimirskii, A. V. (2005). Modeli luchey praktiki dlya telemediciny i elektronnogo zdravohraneniya. Doneck: OOO”Nord”, 36.

3. Kolodii, R. S., Timchenko, O. V. (2009). Metodi pobudovi sensornikh merezh mobil'noho monitorinhu EKH. NU LP, 18-22.

4. Huliyev, Ya.I. (2005). Medicinskiye informacionnyye sistemy: teoriya i praktika. M.: Fizmatlit, 320.

5. Kaplan, N. (2006). Prakticheskiye osnovy analogovyh i cyfrovyh shem. M.: "Tehnosfera", 176.

6. Heili, B. (2005). ZibBee Alliance Tutorial [Electronic resource]. September-November 2005: Proceedings. Mode of access:www.zigbee.org.

7. Pushkaryov, O. I. (2004). ZigBee-moduli XBee: novyye vozmoznosti. Besprovodnyye tehnologivi, № 4, 22-25.

8. Callaway, E. H. (2004). Wireless Sensor Networks: Architectures and Photocols. - New York: CRC Press LLC, 350 .

9. Maksimov, A. (2005). Modelirovanie ustroistv na mikrokontrollerakh s pomoshch'iu prohrammy ISIS iz paketa PROTEUS VSM. Radio, №6, 43-52.

10. Dianov, I. (2010). Kompleksnyye resheniya po GPRSsvyazi $\mathrm{v}$ sistemah promyshlennoy avtomatizacivi i dispetcherizaciyi. Besprovodnyye tehnologiyi, № 4, 32-38.

\section{METHOD OF SECURED INFORMATION ASSESSMENT BASED ON MULTISTAGE DECISION- MAKING PROCESSES (p. 82-85)}

Anton Storchak

One of the components of information security control is to assess the information systems security levels that are designed to determine the effectiveness of the security means.

The aim of this work is to develop a method for assessing the security of information processed in the information system based on controlled multistage decision-making processes that enhance the efficiency of information security, taking into account the characteristics of the process of protection. To achieve this goal it is necessary to determine the value of risk at each stage of the protection process and generally determine the choice of security means that minimize the importance of risk at all stages.

Evaluation process of information systems protection and the process of security means implementation in phases. At each phase a set of data on the security system state is obtained. It depends on the implemented security services that characterize the security system state and influence the choice of protective mechanisms used.

The paper defines the vectors of the evaluation process of security and protection application process to ensure risk values minimization at all stages of the system protection.

Value (8) and (9) along with the rule of protective measures usage (7) determine the procedure for selecting the optimal measures to protect the full statistical description of the system. These expressions are the basis for finding optimal or similar to these algorithms of the security means usage in case of apriority uncertainty. They allow to determine the degree of information systems protection based on the study of changes in its characteristics

Keywords: information system, security assessment, multistage processes

\section{References}

1. Potij, O., Lenshin, A. (2010). Research of information security assessment methods and guidelines design about its improvement on the ground of system approach. Proceedings of Kharkov University of Air Force, 2 (24), p. 85-91.

2. Abramov, M. (2011). Standards in the field of information security needed in the management of organization. Standards and Quality, 1, p. 42-46.

3. Livencev, S., Storchak, A. (2012). Review of security models, secure information systems and use the theory of reflexive games in their building. Information technology in military affairs, 7, p. 66-77.

4. Domarev, V. (2002). Safety of information technologies. Methodology of creation of systems of protection. $688 \mathrm{p}$.

5. Garasymchuk, O., Kostiv, Y. (2011). Assessment of the effectiveness systems protection of information. Bulletin of KNU, 1 (66), p. 16-20.

6. Khnygicheva, A., Novikov, O., Tymoshenko, A. (2010). On modeling of complex information and communications systems security using the logic-probability method. Scientific news "KPI". Information technology, System analysis and management., 6, p. 70-77.

7. Gryschuk, R. (2008). A quantitative estimation protected level is taking into account functioning objects of electroncomputing devices in the conditions of informative conflict. Bulletin of Zhytomyr State Technological University, 3 (46), p. 113-120.

8. Burachok, V. (2011). Algorithm for evaluating the degree of protection of special information and telecommunication systems. Information Security, 3, p. 19-27.

9. Kotenko, I., Stepashkyn, M. (2007). Analysis of computer networks on the basis of modeling the actions of 
intruders and attack graph construction. Proceedings YSA Sciences, 31, p. 126-207.

10. Livencev, S., Storchak, A. (2011). Analysis of methods and means of estimation of information systems protection. The priority directions of development of telecommunications systems and networks. VITI NTU "KPI", p. 136.

11. Livencev, S., Storchak, A. (2012). Models and methods of security analysis of automated systems. XV International Scientific-Practical Conference "Information Security in information and telecommunication systems". Kiev, p. $74-75$.

12. Storchak, A. (2013). Model assessment of information security based on multi-step process driven decision. Special Telecommunication Systems and Information Protection, 2(24), p. 112-117.

13. Repin, V., Tartakovski, G. (1977). Statistical synthesis by a priori uncertainty and adaptation of information systems. Moscow: "Soviet Radio", 432 p.

14. Stratonovich, R. (1966). Conditional Markov processes and their application to the theory of optimal control. MSU, $319 \mathrm{p}$.

\section{MULTI-STEP MODE SIGNAL CONVERSION ALGORITHMS IN HALL SENSOR DEVICES (p. 86-91)}

Zenon Hotra, Roman Holyaka, Victoriya Ilkanych, Tatyana Marusenkova, Valentin Lesynsky, Ivan Godyniuk

This paper presents a numerical and experimental based data analysis of electromagnetic noise immunity in magnetic field measurement devices on Hall sensor transducers. Relevance of this problem takes place in sensor networks with autonomous low-powered sources, magnetic field mapping devices for charged particle accelerators fusion reactors, etc.

The proposed algorithm is based on averaging of several step by step signals, especially, acquired by three consecutive measurements in time interval: $(\mathrm{t}+\mathrm{dt}),(\mathrm{t}),(\mathrm{t}-\mathrm{dt})$. In $(t+d t)$ and $(t-d t)$ time intervals a Hall sensor current pulse magnitude and directions are the same. Contrary to these, in (t) time interval the Hall sensor current has the opposite direction.

It is shown that the efficiency of triple step measurements is three times higher than in double step measurement. The integral performance criterion concept of the signal converter effectiveness is introduced.

The performance criterion factor is defined as a ratio of signal converter electromagnetic noise immunity to its energy consumption. A signal transducer optimized to noise immunity study, its operating modes and Hall sensor parameters are described. Both calculation and experiment results show that the performance criterion factor in triple step measurements is twice higher than in double step measurements

Keywords: Hall sensor, signal transducer, noise-immunity

References

1. Spinelli, E. M., Mayosky, M. A. (2005). Two-Electrode Biopotential Measurements: Power Line Interference Analysis. IEEE Transactions on biomedical engineering, Vol. 52, No. 8, 1436-1442.

2. Fernandez Chimeno, M., Pallàs-Areny, R. (2000). A Comprehensive Model for Power Line Interference in Biopotential Measurements. IEEE Transactions on instrumentation and measurement, Vol. 49, No. 3, 535-540.

3. Akinori Ueno Yasunao Akabane, Tsuyoshi Kato, Hiroshi Hoshino, Sachiyo Kataoka, and Yoji Ishiyama. (2007). Capacitive Sensing of Electrocardiographic Potential Through Cloth From the Dorsal Surface of the Body in a Supine Position: A Preliminary Study. IEEE Transactions on biomedical engineering, 54 (4), 759-766.

4. Hotra, Z., Holyaka, R., Marusenkova, T., Potencki, J. (2010). Signal transducers of capacitive microelectronic sensors. Electronika. Poland, 8, 129-132.
5. Lenz, J., Alan, S. (2006). Edelstein. Magnetic Sensors and Their Applications. IEEE Sensors journal, 6 (3), 631 -649.

6. D.R. Popovic, S. Dimitrijevic, M. Blagojevic, P. Kejik, E. Schurig, R. S. Popovic. (2007). Three-Axis Teslameter With Integrated Hall Probe. IEEE Transactions on instrumentation and measurement, 56 (4), 1396-1402.

7. Jason, A., Fuemmeler Venugopal, Veeravalli, V. (2010). Energy Efficient Multi-Object Tracking in Sensor Networks. IEEE Transactions on signal processing, 58 (7), 3742-3750.

8. Sifuentes, E., Casas, O., Pallas-Areny, R. (2011). Wireless Magnetic Sensor Node for Vehicle Detection With Optical Wake-Up. IEEE Sensors journal, 11 (8), 1669-1676.

9. Bolshakova, I., Holyaka, R., Erashok, V., Kumada, M. (2004). High precision mapper for cyclotron magnet. IEEE Transactions on Applied Superconductivity, 14 (2), 1818-1821.

10. Bolshakova, I., Quercia, A., Coccorese, V., Murari, A., Holyaka, R., Duran, I., Viererbl, L., Konopleva, R., Yerashok, V. (2012). Magnetic Measuring Instrumentation with Radiation-Resistant Hall Sensors for Fusion Reactors: Experience of Testing at JET. JET Preprints and Reports, EFDA-JET-PR(11)54. Available: http://www. iop.org/Jet/fulltext/EFDP11054.pdf.

11. Bolshakova, I., Krukovskii, S., Holyaka, R., Matkovskii, A., Moroz, A. (2001). Ways of providing radiation resistance of magnetic field semiconductor sensors. Radiation Physics and Chemistry, 61, 743-745.

12. Ghahramani Saeed. (2000). Fundamentals of Probability. 2nd Edition. Prentice Hall: New Jersey, 438.

\section{INVESTIGATION OF THE CERTAIN INTERNET DOMAIN STATISTICAL CHARACTERISTICS (p. 91-96)}

Oksana Kyrychenko, Sergey Ostapov, Igor Kanovsky

The review of works, in which statistical characteristics of complex networks were studied on the example of WWW-space, was conducted in the paper. For collecting and processing statistical information of web-pages, the software (crawler), which allowed to conduct network sounding from many entry points was designed and written. Segments net.ua, edu.ua of Ukrainian web-space and segment ac.il of Israeli web-space were investigated. Clusterness coefficients for these segments were calculated. It is shown that increasing the depth of sounding leads only to quantitative changes and qualitative network indicators remain almost unchanged. Probability plots of nodes in degrees on output and input connections and for undirected graphs of the studied segments of web-space are given. It was found that the subnets of input connections (in degree) demonstrate the power-series probability distribution of nodes with the initial section exponent (-2.2), indicating the scaleless nature of the graph.

For the subnet of output connections (out degree) exponential probability distribution of the studied nodes, for which the average degree of nodes was calculated, was obtained. The considered zones do not contain significant features and their level fully corresponds to current trends of the Internet development.

The comparison of the obtained results with literary data was conducted

Keywords: statistical characteristics, degree of node, clusterness coefficient, input connections, output connections

\section{References}

1. Golovach, Yu., Olemskoi, O., fon Ferber, K., Holovatch, T., Mriglod, O., Olemskoi, I., Palchikov, V. (2006). Complex networks. Journal of Physical Studies, 10(4), $247-289$ 
2. Newman, M. E. J. (2001). The structure of scientific collaboration networks. Proc. Natl. Acad. Sci. USA 98(2), 404-409.

3. Newman, M. E. J. (2003). The Structure and Function of Complex Networks. SIAM Review, 45 (2), 167-256.

4. Strogatz, S. H. (2001). Exploring complex networks. (Invited Insight article) Nature, 410, 268-276.

5. Newman, M. E. J. (2000). Models of the small world: a review. J. Stat. Phys. 101, 819-841.

6. Barrat, A., Weigt, M. (2000). On the properties of smallworld networks models. The European Physical Journal B, 13, 547-560.

7. Watts, D. J., Strogatz, S. H. (1998). Collective dynamics of "small-world" networks. Nature, 393, 440-442.

8. Amaral, L. A. N., Scala, A., Barthelemy, M., Stanley, H. E. (2000). Classes of small-world networks. Proc. Natl. Acad. Sci. USA 97 (21), 11149-11152.

9. Watts, D. J. (1999). Small Worlds: The Dynamics of Networks Between Order and Randomness. Princeton Univ. Press, Princeton, 262.

10. Broder, A., Kumar, R., Maghoul, F. et al. (2000). Graph structure in the web. Proceedings of the 9th World Wide Web Conference, Computer networks, 33 (1), 309-320.

11. Baeza-Yates, R., Castillo, C., Efthimiadis, E. N. (2007). Characterization of National Web Domains. Journal ACM Transactions on Internet Technology. 7 (2), Art. 9, $33 \mathrm{pp}$.

12. Kleinberg, J. M. (2000). Navigation in a small world. Nature, 406 (6798.), 845.

13. Newman, M. E. J., Watts, D. J., Strogatz, S. H. (2001). Random graphs with arbitrary degree distribution and their applications. Physical Review, E 6402 (2), 026118 [17 pages]. Preprint cond-mat/0007235. Available: http://xxx.lanl.gov.

14. Lande, D. V., Snarskii, A. A., Bezsudnov, I. V. (2009). Internetika. Navigation in complex networks: models and algorithms. Moscow, 258.

15. Furashev, V. N., Zubok, V. U., Lande, D. (2008). Parameters of the Ukrainian segment of the Internet as a complex network. Open information and computer technology, 40, 235-242.

16. Pasichnik, V. V., Ivanuschak, N. M. (2010). Research and simulation of complex networks. Eastern-European Journal of Enterprise Technologies, 2(3(44)), 43-48.

17. Kyrychenko, O., Kanovsky, I., Ostapov, S. (2013). Software for the study of World Wide Web statistical characteristics. Information processing systems, 2(3), 99-104.

18. Ostapov, S. E., Kanovsky, I. Y., Kyrychenko, O. L. (2013). The Research of Complex Networks in Case of Ukrainian Domain (edu.ua, net.ua) and Israeli Domain ac.il. Ukrainian scientific-practical conference "Problems of Informatics and Computer Technology. Abstracts, 16-21.

\section{PREDICTING RELIABILITY OF STRUCTURES $\mathrm{GaP} \mathrm{SnO}_{2}$ BASED ON 3D MODELS OF THEIR SURFACE (p. 96-98)}

\section{Svetlana Voropaieva}

The application software of Math Lab package for 3D modeling of morphological characteristics of UV radiation sensor surface based on $\mathrm{GaP}$ was used. It was shown that using 3D modeling is a software tool, which allows to visualize heterogeneities of contacts both during their production and selective current control during their operation, analyze the design and technological features of their formation and generate recommendations on their structure improvement. Along with the studies of photoelectric and electro-physical characteristics of semiconductor sensors, 3D modeling of surface morphology of the photosensitive layer of sensors allows to determine the reasons of their degradation parameters and predict the reliability of further operation of the informationmeasuring system.

The revealed morphological surface heterogeneities of the studied UV sensors can be caused by local etching of layer after etching of, or formation of islet oxidizing forms on the surface before applying

Keywords: 3D modeling, UV radiation sensor, information-measuring system

\section{References}

1. Vorobets, G. I., Vorobets, O. I., Voropaeva, S. L., Tanasyuk, Yu. V. (2008). Computer modelling of laser irradiation absorption in multilayer semiconductor structures. Naukovy Visnyk Chernivetskogo Universitetu. Thematic issue "Computer systems and components", Vyp. 426, Part II, 87-92.

2. Vorobets, G. I., Vorobets, O. I., Voropaeva, S. L., Dobrovolsky, Yu. G., Melnychuk, T. A. (2005). Fundamental and applied aspects of laser interaction with materials on the interface $\mathrm{SnO}_{2}$ - $\mathrm{GaP}$ devices: computer modeling and experimental investigations. E-MRS 2005, Spring Meeting, Scientific Programme, May 31 - June 3, 2005, SYMPOSIUM J, P.J-5/19.

3. Vorobets, G.I., Vorobets, O.I., Fedorenko, A.P., Shkavro A.G. (2003) Aging and degradation of aluminium-silicon structures with a Schottky barrier after a pulsed laser irradiation Functional materials, Vol. 10, №3. 468-473.

4. Vorobets, G. I., Vorobets, O. I., \& Strebegev, V. N. (2005) Laser manipulation of clusters, structural defects and nanoaggregates in barrier structures on silicon and binary semi-conductors. Applied surface science, 247(1), 590-601.

5. Komashchenko, V. N., Kolezhuk, K. V., Venher, E. F., Sheremetova, H. Y., Myshchuk, O. A., \& Komashchenko, A. V. (2002). Selektyvnye y shyrokopolosnye ultrafyoletovye sensory. Pysma v ZhTF, 28(19).

6. Malik, A., Sêco, A., Fortunato, E., Martins, R., Shabashkevich, B., \& Piroszenko, S. (1998). A new high ultraviolet sensitivity FTO-GaP Schottky photodiode fabricated by spray pyrolysis. Semiconductor science and technology, 13(1), 102.

7. Mandalapu, L. J., Xiu, F. X., Yang, Z., \& Liu, J. L. (2007). Ultraviolet photoconductive detectors based on Gadoped $\mathrm{ZnO}$ films grown by molecular-beam epitaxy. Solid-state electronics, 51(7), 1014-1017.

8. Ahekian, V. F., Yvanov-Omskyi, V. Y., Kniazevskyi, V. N., Rud, V. Iu., \& Rud, Iu. V. (1998). Optoelektronnye yavlenyia v sloiakh, poluchennykh nytryrovanyem GaP y GaAs. Fyzyka y tekhnyka poluprovodnykov, 32(10). 1203-1205

9. Rembeza, S. Y., Svystova, T. V., Rembeza, E. S., \& Borsiakova, O. Y. (2001). Mykrostruktura y fyzycheskye svoistva tonkykh plenok SnO2. Fyzyka y tekhnyka poluprovodnykov, 35(7), 796-800.

10. Rembeza, S. Y., Rembeza, E. S., Svystova, T. V., \& Borsiakova, O. Y. (2006). Fyzycheskye svoistva plenok SnO. Fyzyka y tekhnyka poluprovodnykov, 40(1), 57-60

\section{DEVELOPMENT OF SCHEMATIC SOLUTIONS FOR AUTOMATIC OLEDS GLOW BRIGHTNESS CONTROL (p. 99-102)}

Zenon Gotra, Pavlo Stakhira, Vladislav Cherpak, Gregory Barylo, Christine Ivanyuk, Igor Helzhynskyy

An overview of existing energy-saving lighting sources for premises was conducted in the paper. The method of measuring the brightness of organic light-emitting structure, which consists of a measuring part, which is carried out on the developed measuring device and a mathematical part of direct calculation of the OLEDs glow brightness was proposed. The measuring was carried out on the basis of the developed structure and proposed method for brightness measurement.

Current-voltage and voltage-brightness characteristics of organic light-emitting diode were shown.

A circuit solution to the OLEDs glow brightness automatic control, depending on the room lightning was de- 
veloped. The electrical schematic diagram in the program environment Proteus was modeled and optimized.

The proposed diagram allows optimizing the performance of light-emitting device using the OLEDs and their control system, reducing power consumption. During the optimization, the optimum values for parameters of electrical diagram and microcontroller code table were selected

Keywords: OLED, light-emitting layer, optical power, radiation spectrum, microcontroller

\section{References}

1. Sorokin, V (2009). Organic light-emitting structure - Technologies of XXI Century. Technology and design in electronic equipment, № 1,3-4.

2. Kalyani, N, Dhoble (2012). Organic light emitting diodes: Energy saving lighting technology - A review/Renewable and Sustainable Energy Reviews, № 16, 2696- 2697.

3. Staharny, C. (2010). Prospects for organic light diodes in lighting systems. Modern lighting, № 3, 23-30.

4. Koch, N. (2007). Organic Electronic Devices and Their Functional interfaces. A european journal of chemical physics and physical chemistry,№8,1438-1455.

5. S. Tyagi. (1991). Introduction to semiconductor materials and devices. John Wiley \& Sons, New York, 235-237.

6. Brutting, W., Berleb, S., Muckl, A. Device physics of organic light-emitting diode based on molecular materials /W. Brutting, // Organic Electronics. - 2001. - № 2. P. 1-3.

7. Forrest, S. R. Measuring the efficiency of organic lightemitting devices/ S. R. Forrest, D. C. Bradley, M. E. Thompson // Edvanced materials. - 2003.- p.1043-1047.

8. Tang, C. W. Organic electroluminescent diodes / C.W.Tang, S.A. Vanslyke. // Applied Physics Journal. 1987. - vol,51. - pp. 913-915.

9. Park, J. W. Large-area OLED lightings and thier application /J. W. Park, D. C. Shin, S. H. Park // Semiconductor Science and Technology - 2011. - vol.26. - P. 034002034011.

10. Maximov, A. (2005). Modeling devices with microcontrollers using the ISIS package of PROTEUS VSM. Radio,№4,26-27.

\section{EPITAXIAL STRUCTURES ON THE BASE OF $\mathrm{Cd}_{1-\mathrm{x}} \mathrm{Zn}_{\mathrm{x}} \mathrm{Sb}$ AND LASER OPTIMIZATION OF THEIR PROPERTIES (p. 103-106)}

Yuriy Obedzynskyi, Andriy Savchuk, Viktor Strebegev, Ivan Yuriychuk

Photosensitive elements on the basis of $\mathrm{CdSb}$ and $\mathrm{Cd}_{1-\mathrm{x}} \mathrm{Zn}_{\mathrm{x}} \mathrm{Sb}$ single crystals, doped with Te, In, Ga, are obtained by liquid-phase epitaxy. $\mathrm{CdSb}$ and $\mathrm{Cd}_{1-\mathrm{x}} \mathrm{Zn}_{\mathrm{x}} \mathrm{Sb}$ epitaxial layers are exposed to pulsed laser radiation with energy density $2-10 \mathrm{~J} / \mathrm{cm}^{2}$. CdSb layers surface acquires a more ordered planar morphology, density of structural defects in the heterojunction and width of the transition region are reduced at optimal mode of laser processing speed. Laser beam stimulates transformation of metastable cadmium antimonide phase inclusions into $\mathrm{CdSb}$ equilibrium phase. Photosensitivity of $\mathrm{Cd}_{1-\mathrm{x}} \mathrm{Zn}_{\mathrm{x}} \mathrm{Sb}$ based heterojunction cells is increased. The optimal level of photosensitivity is achieved by doping basic single crystals by Te. Interference bandpass filters in the form of $\mathrm{SiO}, \mathrm{Ge}, \mathrm{BaF}_{2}, \mathrm{ZnS}$ thin films on $\mathrm{ZnSb}$ single crystal are designed. Selection of incident IR radiation on the photosensitive element by such filter makes it possible to block solar and other noises in the wavelength range $\lambda<2$ micron

Keywords: semiconductor, photosensitivity, epitaxial structure, laser, crystal, CdSb, $\mathrm{Cd}_{1-\mathrm{x}} \mathrm{Zn}_{\mathrm{x}} \mathrm{Sb}$, heterojunction, impurity

\section{References}

1. Dremlyuzhenko, S. G., Voloshchuk, A. G., Gritsyuk, B. N., Rarenko, I. M., Strebezhev, V. N. (2003). Chemical etching of CdSb single crystals: Thermodynamic analysis. Inorganic Materials, 39(12), 239-1245.

2. Ashcheulov, A. A., Gutsul, I. V., Manyk, O. N., Manyk, T. O., Marenkin, S. F. (2010). CdSb, ZnSb, and CdxZn1xSb low-symmetry crystals: Chemical bonding and technological aspects. Inorganic Materials, 46(6), 574-580.

3. Kashiwaba, Y., Ohya, N., Ikeda, T. (1986). Preparation of electrical properties of $\mathrm{CdSb}$ thin films. Japanese Journal of Applied Physics, Part 1, 25(12), 1855-1861.

4. Kashiwaba, Y., Abe, H., Ikeda, T., Horie, H., Nakamura, M., Shoubuzawa, Y. (1996). Selective migration of $\mathrm{Cd}$ in amorphous Cd-Sb films. Jpn.J.Appl.Phys., 35(7), 3825-3829.

5. Gritsyuk, B. M., Galochkin, O. V., Rarenko, A. I., Strebezhev, V. M. (2003). IR photodetectors on CdSb, In4Se3, In4Te3-epitaxial barrier structures. Proceedings of SPIE, 5065, 39-145.

6. Vorobets, G. I., Vorobets, O. I., Strebegev, V. N. (2005). Laser manipulation of clasters, structural defects and nanoaggregates in barrier structures on silicon and binary semiconductors. Applied Surface Science, 247, 590-601

7. Feucht, D. L., Milnes, A. G. (1970). Heterojunctions and metal-semiconductor junctions. N.Y: Academic Press, 432.

8. Mohamed, A. A., Saleh, S. A., Abou-Saif, E. A., Abd-Rabom. (1983). On the identification of new and normal phases in system of cadmium-antimony alloys. Phys. Status Solidi, 78, 705-716.

9. Tengå, A., Lidin, S., Belieres, J.-P., Newman, N., Wu, Y., Häussermann, U. (2008). Metastable Cd4Sb3: A complex structured intermetallic compound with semiconductor properties. Journal of the American Chemical Society, 130(46), 15564-15572.

10. Dremluzhenko, S. G., Konopatseva, L. I., Kulikovskaya, S. M., Stetsko, Yu. P., Strebezhev, V. N., Rarenko, A. I., Ostapov, S. E. (1999). Interference IR-filters on the CdSb monocrystal substrates. Proceedings of SPIE, 3890, 104-110.

\section{FABRICATION AND PROPERTIES OF p-n-JUNC- TIONS BASED ON Cd ${ }_{1-\mathrm{x}} \mathbf{Z n}_{\mathrm{x}} \mathrm{Te}$ (p.107-109)}

Viktor Brus, Mariya Ilashchuk, Bohdan Griytsyk, Orest Parfenyuk, Pavlo Maryanchuk

Electrical properties of semiconductor p-n-junctions, fabricated by the illumination of $\mathrm{Cd}_{1-\mathrm{x}} \mathrm{Zn}_{\mathrm{x}}$ Te crystals by powerful laser pulses, were investigated.

The fabrication of barrier structures was carried out on the base of $\mathrm{Cd}_{1-\mathrm{x}} \mathrm{Zn}_{\mathrm{x}}$ Te single crystals with n-type of conductivity, grown by the Bridgman method at controllable cadmium vapor pressure. The region with p-type of conductivity was created by means of a powerful ruby laser $(\lambda=0.694 \mu \mathrm{m}$, absorption coefficient in $\mathrm{CdTe} \alpha=6.104 \mathrm{~cm}^{-1}$ ).

The prepared structures were established to be abrupt p-n-junctions. Their I-V characteristics are determined by the generation-recombination processes within the space charge region as well as by the recombination at the interface between recrystallized layer and bulk semiconductor.

The $\mathrm{C}-\mathrm{V}$ characteristics, measured at different frequencies of small amplitude $(10 \mathrm{mV})$ AC signal, provide evidence on the presence of the series resistance and surface states at the interface between recrystallized layer and bulk semiconductor that is in good correlation with the results obtained from the I-V characteristics

Keywords: CdTe, p-n-junctions, laser, illumination, evaporation, diffusion, recombination, vacancies, current, signal

References 
1. Zanio, K. R. (1978) Cadmium telluride. Semiconductors and Semimetals. Academic Press, New York, V.13, 236

2. Shkubatyuk, P. S. (1999). The fabrication of barrier structures by a continuous laser illumination of wide band gap AIIBVI semiconductors. Inorganic materials., 35(9), 1045-1047.

3. Medvid, A., Onufrijevs, P., Mozolevskis, G., Dauksta, E., Rimsa, R. (2012). Two-stage model of nanocone formation on a surface of elementary semiconductors by laser radiation. Nanoskale Research Letter, 7, 428-514.

4. Huang, Y., Zhao, K., Lu, H., Jin, K., He, M., Chen, Z., Zhou, Y., Yang, G. (2006). Multifunctional characteristics of $\mathrm{BaNb}_{0.3} \mathrm{Ti}_{0.7} \mathrm{O}_{3} / \mathrm{Si}$ p-n junctions. Appl. Phys. Let., 88, 0619119 .

5. Shulpina, I. L., Zelenina, N. K., Matveev, O. A. (2000). Thermal effect of pulsed laser illumination on the real structure of CdTe single crystals. Semiconductors, 42(3), 548-552.

6. Baydulaiva, A., Bulah, M. B., Vlasenko, A. I., Lomovtsev, A. B., Mozol, P. E. (2004). The dynamics of the formation of barrier structures in $\mathrm{p}$-CdTe crystals under pulsed laser illumination. Semiconductors, 38(1), 26-29.

7. Baydulaiva, A., Vlasenko A. I., Gokovenko B. L., Lomovtsev A. B., Mozol P. E. (2000). The measurements of structure defects in p-CdTe single crystals under the effect of laser shock wave. Semiconductors, 34(4), 443-446.

8. Sze, C. M. Physics of semiconducting devices - M.: "Energiya", 1973, 655p.

9. Babentsov, V. I., Baydulaiva, A., Bulah, M. B., Gorban, S. I., Mozol, P.E. (1988). Te effect of laser illumination on structure and recombination properties of single crystalline CdTe. Poverhnost. Fizika, hivia, mehanika, 12, 144-147.

10. Matveev, O. A., Terentev, A. I.(2000). The fundamental principles of the series annealing of $\mathrm{CdTe}: \mathrm{Cl}$ sample for the preparation of semiisolating crystals. Semiconductors, 34(11), 1316-1322.

\section{FEATURES OF DIAGNOSTIC INFORMATION SEARCH FOR SOLVING TASKS OF INTELLIGENCE DIAGNOSTICS (p. 109-112)}

Vasyl Lyashkevych, Roman Makarchuk

Ensuring reliable operation of computer means (CM) for companies and enterprises, where information technologies are closely integrated into the production process is an actual and important task, which prevents the technological process stoppage or loss of important data. Today, the problem of formalization of engineers-diagnosticians' experience and processing of diagnostic information (DI) provided by them, which is the main component of improving the efficiency of CM diagnostic tools during the operation is partially solved. However, the problem of developing DI search tools as constituent means of ID remains topical. Taking into account the trends of intensive development of $\mathrm{CM}$, the features of $\mathrm{CM}$ as diagnostics objects (DO) were given in the paper, and the analysis of the interaction process of an engineer-diagnostician with retrieval systems during solving the ID problems was carried out.

At each stage of solving ID problems, diagnostician, if necessary, searches needed DI.

The problem is that within the one query to the IRS (information retrieval system), he cannot cover the actual situation that leads to the stepwise search of DI. Each step is accompanied by its features. On the basis of the conducted studies and analysis it can be stated about the feasibility of using search services as constituent methods and tools of CM intelligence diagnostics

Keywords: computer means, intelligence diagnostics, diagnostic information, search services

References
1. Lokazyuk, V. M., Savchenko, Yu. G. (2004). Reliability, control, diagnosis and modernization PC. Kiev, Ukraine: Academy, 376.

2. Pomorova, O.V., Gnatchuk, Ye.G. (2008). Efficiency of the fuzzy expert system diagnostics of computer means. Radioelectronic and computer systems, 5 (32), 121-127.

3. Kryvulya, G.F., Kucherenko, D.Ye., Davydov, A.A. (2010). Diagnosing failures of computer systems using intelligent tools. Information Technology. KhNTU, 2(38), 266-271.

4. Lokazyuk, V. M., Lyashkevych, V. Ya. (2005). Conceptual model of search the diagnostics information for testing computer devices. Information technology and computer engineering, 3, 221-229.

5. Pomorova, O. V. (2007). Theoretical foundations, methods and means of intelligence diagnostics computer systems. Khmelnytskyi, Ukraine: Triada-M, 253

6. Lyashkevych, V., Makarchuk, R. (2013). Actuality development searching service for solution tasks of intelligence diagnostic computer means. Proceeding Of the 6-th International Conference ACSN-2013. Lviv, Ukraine: Ukraine Technology, 32-34.

7. Kryvulya, G. F., Kucherenko, D. Ye. (2009). Intelligence diagnostic means of condition of administer computer systems. Information-administer systems on railway transport, 4, 23-28.

8. The research model of user behavior when dealing with search engines Available: http://housecomputer.ru/seo/ behavior_user_seo/behavior_user_seo.html.

9. Pomorova, O. V., Olar, O. Ya. $(200 \overline{8})$. Generalized formal model of intelligent microprocessor-based diagnostic devices and systems. Radioelectronic and computer systems, 5 (32), 133-138.

10. Lyashkevych, V. Ya., Makarchuk, R. I., Nadeev, A. V. (2013). Using situational approach for buildan ontology of subject domain «Intelligence diagnostic of computer means». Scientific Bulletin of Khmelnytskyi National University, 5, 152-158.

\section{PROPERTIES OF Optical and photovoltaic cells ON} THE BASE OF In ${ }_{4} \mathrm{Se}_{3}, \mathrm{In}_{4}\left(\mathrm{Se}_{3}\right)_{1-\mathrm{x}} \mathrm{Te}_{3 \mathrm{x}}$ CRYSTALS (p. 113-116)

Volodymyr Strebegev, Viktor Strebegev, Sergiy Nichyi, Ivan Yuriychuk

Theoretical calculations of thin-film interference systems for design of IR-filters on the base of $\operatorname{In}_{4}\left(\mathrm{Se}_{3}\right)_{1-\mathrm{x}} \mathrm{Te}_{3 \mathrm{x}}$ solid solution crystals are carried out. Interference-absorptive bandpass filters on $\operatorname{In}_{4}\left(\mathrm{Se}_{3}\right)_{1-\mathrm{x}} \mathrm{Te}_{3 \mathrm{x}}$ crystal with different cutting wavelength position depending on the composition $\mathrm{x}$ of the solid solution are produced by vacuum evaporation. Spectral transmission characteristics of the filters and dependence of their parameters on structural perfection of substrates and filter films are studied. Photosensitive elements on the base of $\operatorname{In}_{4}\left(\mathrm{Se}_{3}\right)_{1-x} \mathrm{Te}_{3 \mathrm{x}}$ homo-epitaxial heterojunctions are designed and laser correction of their photosensitivity spectral characteristics is carried out.

Surface morphology of epitaxial layers is studied by electron raster microscopy. Temperature dependence of $\mathrm{In}_{4}\left(\mathrm{Se}_{3}\right)_{1-\mathrm{x}} \mathrm{Te}_{3 \mathrm{x}}$ based photosensitive elements is measured. Mechanical strength and stability of filters and photosensitive elements spectral characteristics under cooling are studied. Laser treatment of photosensitive elements significantly increases photo-response signal of epitaxial structures at optimal operating temperatures

Keywords: interference filter, band-pass filter, transmittance, crystals, $\operatorname{In}_{4}\left(\mathrm{Se}_{3}\right)_{1-\mathrm{x}} \mathrm{Te}_{3 \mathrm{x}}, \mathrm{In}_{4} \mathrm{Se}_{3}$, heterostructure, heterojunction, solid solution, photosensitivity

\section{References}

1. Gertovich, T. S., Grineva, S. I., Ogorodnik, A. D., Stolyarchuk, O. T., Tovstyuk, K. D., Scharlay, E. S (1985). Electrical and optical properties of 
$\mathrm{In}_{4}\left(\mathrm{Se}_{3}\right)_{1-\mathrm{x}} \mathrm{Te}_{3 \mathrm{x}}(0,60<\mathrm{x}<1,00)$ solid solutions. Ukrainian Journal of Physics, 30, 624-628.

2. Gritsyuk, B. M., Moschkova, T. S., Ogorodnik, A. D., Rarenko, I. M., Volyanska, T. A. (1999). $\operatorname{In}_{4}\left(\mathrm{Se}_{3}\right)_{1-\mathrm{x}} \mathrm{Te}_{3 \mathrm{x}}$ solid solution - a material for optical absorption filters. Journal of Applied Spectroscopy, 66, N4, 577-579.

3. Moschkova, T. S., Melnychuk, T. A., Ogorodnik, A. D., Strebegev, B. N. (2005). Effect of doping on optical and photovoltaic properties of $\operatorname{In}_{4}\left(\mathrm{Se}_{3}\right)_{1-x} \mathrm{Te}_{3 \mathrm{x}}$ single crystals. Ukrainian Journal of Physics, 50, N12, 1254-1258.

4. Melnychuk, T. A, Strebegev, V. N., Vorobets, G. I. (2007). Laser synthesis of thin films and layers of $\mathrm{In}_{4} \mathrm{Se}_{3}, \mathrm{In}_{4} \mathrm{Te}_{3}$ and modification of their structure. Applied Surface Science, 254, 1002.

5. Obedzynskyi, Yu. K., Strebegev, V. N., Gritsyuk, B. N., Strebegev, V. V., Yuriychuk, I. M. (2012). Photosensitive heterostructures and infrared filters on $\mathrm{CdSb}$ and $\mathrm{In}_{4} \mathrm{Se}_{3}$ single crystals. Eastern-European Journal Of Enterprise Technologies, 6(12(60)), 44-46.

6. Gritsyuk, B. M., Galochkin, O. V., Rarenko, A. I., Strebezhev, V. N. (2003). IR-photodetectors on CdSb, $\mathrm{In}_{4} \mathrm{Se}_{3}$, $\mathrm{In}_{4} \mathrm{Te}_{3}$-epitaxial barrier structures. Proceedings of the SPIE, 5065, 139-145.

7. Vorobets, G. I., Vorobets, O. I., Strebegev, V. N. (2005). Laser manipulation of clasters, structural defects and nanoaggregates in barrier structures on silicon and binary semiconductors. Applied Surface Science, 247, 590-601.

8. Losovyj, Ya. B., Makinistian, L., Albanesi, E. A., Petukhov, A. G., Liu, Jing, Galiy, P., Dveriy, O. R., Dowben, P. A. (2008). The anisotropic band structure of layered $\mathrm{In}_{4} \mathrm{Se}_{3}(001)$. Journal of applied physics, 104, 083713-1083713-7.

9. Makinistian, L., Albanesi, E. A., Gonzalez Lemus, N. V., Petukhov, A. G., Schmidt, D., Schubert, E., Losovyj, Ya.B., Galiy, P., Dowben P.A. (2010). Ab initio calculations and ellipsometry measurements of the optical properties of the layered semiconductor $\mathrm{In}_{4} \mathrm{Se}_{3}$. Phys.Rev.B., 81, N7, 075217-1-075217-8.

10. Benramdane, N., Misho, R. H. (1995). Structural and optical properties of $\mathrm{In}_{4} \mathrm{Se}_{3}$ thin films obtained by flash evaporation. Solar Energy Materials and Solar Cells, 37, N3-4, 367-377.

11. Xingfu, Li., Bin, Xu, Gongqi, Yu, Xue, Li, Lin, Yi. (2013). Anisotropic optical and thermoelectric properties of $\mathrm{In}_{4} \mathrm{Se}_{3}$ and $\mathrm{In}_{4} \mathrm{Te}_{3}$. Journal of applied physics, 113, 203502 .

\section{RESEARCH OF THE INTERMITTENT FAILURES PREDICTING METHOD BASED ON THE THEORY OF RUNS (p. 116-119)}

Leonid Nedostup, Myroslav Kiselychnyk, Pavlo Zayarnyuk

Intermittent failures of REE (radio electronic equipment) are hard to predict, while they may lead to critical consequences. We propose the method, based on the theory of runs of random processes for predicting the parametric reliability of REE.

This method allows predicting the duration of runs, their number and average duration of one run in the interval from 0 to $\mathrm{T}$, on condition of the known three-dimensional random variable distribution law. The analytical and graphic dependencies for determining the parameters of the random process of change of REE defining parameter are given in the paper. The proposed method allows taking into account intermittent failures and predicting reliability for stationary and non-stationary processes. In addition, as a result of some simplifications, predicting is carried out with the known regression of expected value and variance, as well as the known random process distribution law.

The main advantage of the developed method is that it allows predicting the reliability of radio electronic equipment both in the case of the stationary process, and in the cases of the process with periodic component and quasideterministic random process

Keywords: runs, intermittent failures, reliability, reliability predicting, theory of runs

\section{References}

1. Gudkov, M. (2010) Process of forecasting reliability electronic equipment when operating as the control parametrivyu. Weapons systems and military equipment, N4 (24), 32-35.

2. Sumich, D., Vlasich, R. (2009) An assessment of HF NVIS radio system reliability. POWA - 10.

3. Nedostup, L., Kiselychnyk, M., Bobalo, Y., Melen, M. (2012) Predicting the reliability of radio-electronic devises by the monitoring of production defectiveness. Electronic Review,R88NR, 3a,33-36.

4. Rise,S. (1944,1945)MathematicalAnalysesofRandomNoi se.Bell. Syst. Thech. J. (23,24).

5. Tikhonov, V. (1970). Emissions of random processes. Moscow: Science, 392

6. Tikhonov, V. (1987) Emissions trajectories of random processes. Moscow: Sciens, 306.

7. Tikhonov, V. (1982) Statistical radio engineering.M.: Radio and communication. 624.

8. Sveshnikov, A. (1968). Applied methods of the theory of random functions. Moscow: Science, 464.

9. Sveshnikov, A. (1972) Fundamentals of the theory of errors - Leningrad: Len.univ ed., 122.

10. Volkov, L., Shyshkevich, A. (1975) Reliability of flying apparats. Moscow: Higher School, 296.

11. Nedostup, L., Kiselychnyk, M., Bobalo, Y. (1998). Fundamentals of reliability of electronic devices. Lviv: Publishing House of Lviv Polytechnic University, 219. 